\title{
Aplikasi Listrik Pintar Berbasis Android
}

\author{
Aji Fitrah Marisman \\ Prodi Teknik Informatika \\ Jurusan Teknik Informatika dan Komputer, PNJ \\ Depok, Indonesia \\ fitrah.marisman@gmail.com
}

\author{
Anita Hidayati \\ Prodi Teknik Informatika \\ Jurusan Teknik Informatika dan Komputer, PNJ \\ Depok, Indonesia \\ anita.hidati@tik.pnj.ac.id
}

Diterima: 5 Maret 2015. Disetujui: 3 April 2015. Dipublikasikan: Mei 2015

\begin{abstract}
Abstrak --Untuk prosedur tagihan listrik, PLN menerapkan dua sistem yakni, sistem prabayar dan sistem pasca bayar. Sistem pasca bayar merupakan sistem yang banyak diminati masyarakat karenamereka dapat menggunakan listrik terlebih dahulu sebelum membayarnya. Hal ini memaksa PLN untuk mencatat data meter pelanggan ke setiap rumah pelanggan. Untuk mendapatkan efisiensi pencatatan data pelanggan, maka dibutuhkan sebuah sistem untuk mencatat data meter pelanggan dan dapat mengirimkannya langsung ke server.

Aplikasi ini bernama listrik pintar yang memiliki fungsi untuk mencatat data meter pelanggan, mengambil titik latitude dan longitude lokasi meter, mengambil foto meter dan melihat hasil catat meter. Aplikasi ini dibangun untuk platform android. Hal ini bertujuan mempercepat pendistribusian data ke server. Pembuatan aplikasi ini menggunakan metode Software Development Cycle(SDLC). Metode ini memiliki empat tahapan yakni analisa kebutuhan pengguna, spesifikasi perancangan, pengembangan. pengujian dan implementasi
\end{abstract}

Kata Kunci: Pelanggan, Catat Meter, Data Meter, Foto Meter, Hasil Catat Meter, Pelanggan

\section{PENDAHULUAN}

Listrik menjadi kebutuhan primer bagi masyarakat indonesia. Selimuh aktivitas masyarakat indonesia bergantung pada pasokan listrik. PLN merupakan perusahaantunggal yang memproduksi listrik bagi seluruh elemen masyarakat. Kini, aktivitas masyarakat terbantu dengan adanya pasokan listrik dari PLN.

Untuk prosedur tagihan listrik, PLN menerapkan dua sistem yakni, sistem prabayar dan sistem pasca bayar. Sistem prabayar merupakan konsep terbaru yang dicanangkan oleh PLN dimana pelanggan membeli energi listrik sebelum menggunakannya. Sedangkan sistem pasca bayar merupakan konsep lama dimana pelanggan menggunakan listrik terlebih dahulu lalu membayar pada bulan selanjutnya.

Namun sistem prabayar yang ditawarkan oleh PLN tidak begitu diminati oleh masyarakat dengan berbagai macam alasan. Mereka cenderung lebih menyukai sistem paseabayar. Selama menggunakan listrik pasca bayar, PLN harus mendatangi rumah pelanggan untuk mencatat masing - masing meteran pelanggan. Hal ini tentu menjadi tantangan tersendiri bagi PLN.

Dengan adanya sistem ini, kegiatan PLN dalam melakukan pencatatan data meter pelanggan menjadi lebih efisien.

Aplikasi ini bernama Listrik Pintar yang ditujukan bagi Petugas PLN untuk memeriksa meteran listrik pelanggan. Aplikasi memiliki fungsi untuk mencatat data meter pelanggan, mengambil titik latitude dan longitude lokasi meter, mengambil foto meter dan melihat hasil catat meter. Aplikasi ini dibangun untuk platform android yang bertujuan untuk mempercepat pendistribusian data ke server.

\section{TINJAUAN PUSTAKA}

\section{A. Android}

Menurut Nazrudin Safaat H (2011 : 1), Android adalah sebuah sistem operasi untuk perangkat mobile berbasis linux yang mencakup sistem operasi, middleware, dan aplikasi[5]. Android adalah sistem operasi untuk telepon seluler yang berbasis Linux. Android menyediakan platform terbuka bagi para pengembang untuk membuat aplikasi mereka sendiri.

Awalnya, Google Inc. membeli Android Inc. yang merupakan pendatang baru yang memuat piranti lunak untuk ponsel atau smartphone. Untuk mengembangkan Android dibentuklah Open Handset Alliance, konsorsium dari 34 perusahaan 
piranti keras, piranti lunak dan telekomunikasi, termasuk Google, HTC, Intel, Motorola, Qualcomm, T-Mobile dan Nvidia. Pada saat perilisan perdana Android, 5 November 2007, Android bersama Open Handset Alliance menyatakan mendukung pengembangan open source padaperangkat mobile. Di lain pihak, Google merilis kode - kode Android di bawah lisensi Apache, sebuah lisensi perangkat lunak dan open platform perangkat seluler.

\section{B. JSON}

JSON (JavaScript Object Notation) adalah format pertukaran data yang ringan, mudah dibaca dan ditulis oleh manusia, serta mudah diterjemahkan dan dibuat (generate) oleh computer[2]. Format ini dibuat berdasarkan bagian dari Bahasa Pemrograman JavaScript, Standar ECMA-262 Edisi ke-3 - Desember 1999. JSON merupakan format teks yang tidak bergantung pada bahasa pemrograman apapun karena menggunakan gaya bahasa yang umum digunakan oleh programmer keluarga $\mathrm{C}$ termasuk $\mathrm{C}, \mathrm{C}++, \mathrm{C \#}$, Java, JavaScript, Perl, Python dll. Oleh karena sifat - sifa tersebut, menjadikan JSON ideal sebagai bahàsa pertukaran data. JSON terbuat dari dua struktur:

Kumpulan pasangan nama/nilai. Pada beberapa bahasa, hal ini dinyatakan sebagai objek (object), rekaman (record), struktur (structure), kamus (dictionary), tabel hash (hash table), daftar berkunci (keyed list), atau associative array.

Daftar nilai terurutkan (an ordered list of values). Pada kebanyakan bahasa, hal ini dinyatakan sebagai larik (array), vektor (vector), daftar (list), atau urutan (Sequence).

\section{Java}

Menurut Abdul Kadir (2003:12) Java adalah bahasa pemrograman serbaguna. Java dapat digunakan untuk membuat suatu program sebagaimana yang diinginkan. Java juga mendukung aplikasi client/server, baik dalam jaringan lokal (LAN) maupun jaringan berskala luas (WAN).[3]

Java dikembangkan oleh Sun Microsystems pada Agustus 1991. Java disebut juga merupakan hasil perpaduan sifat dari sejumlah bahasa pemrograman, yaitu $\mathrm{C}$ dan $\mathrm{C}++$. Pemrograman Java bersifat tidak bergantung pada platform, yang artinya java dapat dijalankan pada sembarang komputer dan bahkan pada sembarang sistem operasi. Sebagaimana halnya $\mathrm{C}++$, salah satu bahasa yang mengilhami Java. Java juga merupakan bahasa pemrograman berorientasi objek.

Sebagai bahasa pemrograman berorientasi objek, Java menggunakan kelas untuk membentuk suatu objek.

Sejumlah literatur menyebutkan Java adalah hasil perpaduan sifat dari sejumlah bahasa pemrograman lain seperti $\mathrm{C}$. $\mathrm{C}++$, Object-C, SmallTalk dan Common LISP. Selain itu Java telah dilengkapi unsur keamanan. Java juga menambahkan paradigma pemrograman sederhana.[1]

Ketidakbergantungan pada platform lain sering dinyatakan dengan istilah portabilitas. Yang menarik, tingkatportabilitas Jaya tidak hanya pada program sumber (source code) namun pada tingkat code biner yang disebut bytecode. Dengan demikian, misalnya program java telah dikompilasi pada komputer bersistem operasi windows makahasil komplasi dapat dijalankan pada Linux atau MacOS secara langsung tanpa kompilasi ulang. Untuk mendapatkan efisiensi pencatatan data pelanggan, maka dibutuhkan sebuah sistem untuk meneatat data meter pelanggan dan dapat mengirimkannya langsung ke server.

\section{Database}

Database atau basis data adalah kumpulan data yang disimpan secara sistematis di dalam komputer dan dapat diolah atau dimanipulasi menggunakan perangkat lunak (program aplikasi) untuk menghasilkan informasi. Pendefinisian basis data meliputi spesifikasi berupa tipe data, struktur, dan juga batasan - batasan data yang akan disimpan. Basis data merupakan aspek yang sangat penting dalam sistem informasi dimana basis data merupakan gudang penyimpanan data yang akan diolah lebih lanjut.

Basis data menjadi penting karena dapat menghindari duplikasi data, hubungan antar data yang tidak jelas, organisasi data, dan juga update yang rumit. Proses memasukkan dan mengambil data ke dan dari media penyimpanan data memerlukan perangkat lunak yang disebut dengan sistem manajemen basis data (database management system | DBMS).

\section{METODE PENGEMBANGAN APLIKASI}


Metodologi pelaksanaan pekerjaan menggunakan metode System Development Life Cycle (SDLC). Dalam rekayasa sistem dan rekayasa perangkat lunak SDLC adalah proses pembuatan dan pengubahan sistem serta model dan metodologi yang digunakan untuk mengembangkan sistem-sistem tersebut[4]. Konsep ini umumnya merujuk pada sistem komputer atau informasi. Penggunaan metode SDLC terdiri dari beberapa tahapan yaitu:

\section{A. Analisa Kebutuhan Pengguna}

Analisa kebutuhan pengguna terhadap sistem yang akan dibangun adalah tahap awal yang digunakan dalam metodologi menggunakan SDLC.

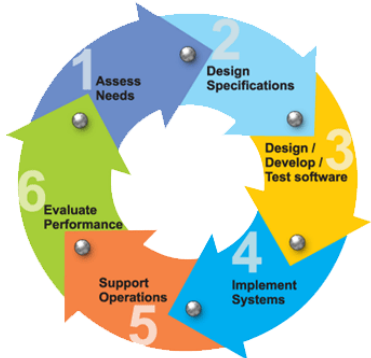

Gambar 1 System Development Life Cycle (SDLC)

B. Spesifikasi Perancangan

Melakukan desain database menggunakan kaidah Relational Database Management System (RDBMS). Perancangan Database adalah proses untuk menentukan isi dan pengaturan data yang dibutuhkan untuk mendukung berbagai rancangan sistem.

\section{Pengembangan}

Pada tahap ini juga dilakukan pemrosesan data yang sudah dimasukkan dalam tábel. Data yang sudah diproses dapat menghasilkan laporan-laporan (output) sesuai kebutthan pengguna.

\section{Pengujian}

Tahap pengujian diperlukan untuk memastikan semua tahapan sebelumnya (tahap analisa kebutuhan pengguna, tahap perancangan dan tahap pengembangan) sudah diselesaikan dengan benar. Jika ada kesalahan yang bersifat kecil, maka akan diperbaiki secara cepat tanpa harus mengulang tahapan sebelumnya. Kesalahan yang bersifat kecil tidak menyebabkan adanya perubahan mendasar pada proses bisnis saat analisa kebutuhan pengguna dibuat.

\section{E. Implementasi}

Tahap implementasi akan dilaksanakan saat tahap pengujian sudah dilewati dengan sempurna. Pada tahap ini pengguna sudah siap menggunakan aplikasi yang sudah diujicoba. Jika masih ada perubahan ataupun penambahan berskala kecil (tidak mengubah proses bisnis yang sudah disepakati) dapat dilakukan pada tahap pemeliharaan.

\section{HASIL DAN PEMBAHASAN}

A. Splashscreen
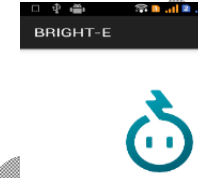

BRIGHT ELECTRICITY BRIGHT-E

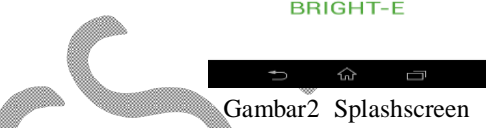

Halaman Splashscreen berfungsi untuk menampilkan lampilan awal dan nama aplikasi.

B. Login

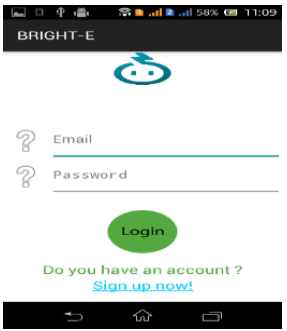

Gambar3 Login

Halaman login berfungsi untuk memproses login Petugas PLN yang akan menggunakan aplikasi ini. Pada halaman login terdapat email dan password untuk melakukan login. Sebelum login, Petugas PLN harus melakukan sign up terlebih dahulu.

C. Sign up

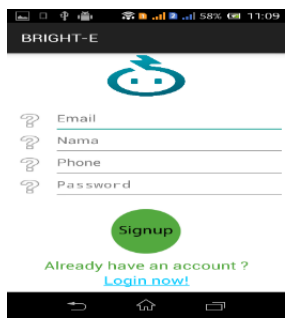

Gambar4 Sign up 
Halaman Sign up berfungsi untuk memproses pendaftaran akun Petugas PLN di aplikasi ini. Petugas PLN membutuhkan email, nama, handphone dan password untuk melakukan pendaftaran akun. Setelah melakukan sign up, Petugas PLN dapat langsung login ke aplikasi.

D. Мепи

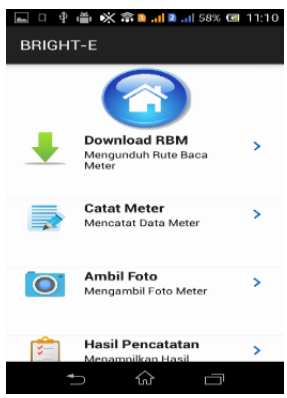

Gambar 5 Menu

Halaman menu berisi tentang daftar menu aplikasi ini. Daftar menu terdiri dari Download RBM, Catat Meter, Ambil Foto, Hasil Pencatatan, Setting, Bantuan, Tentang Aplikasi dan Keluar.

\section{E. Download RBM}

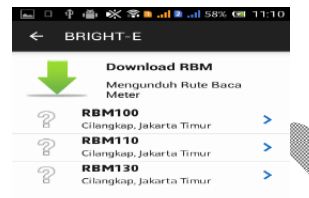

Gambar \& Download RBM

Halaman Download RBM berisi tentang daftar RBM yang ada pada database. RBM merupakan rute baca meter. Apabila salah satu kode rbm dipilih, maka akan muncul daftar pelanggan.

\section{F. Daftar Pelanggan}

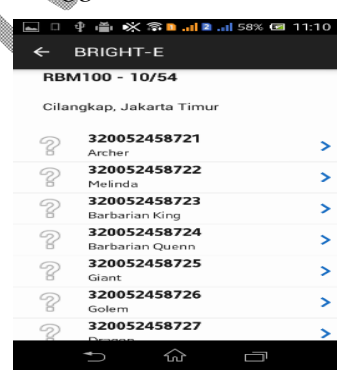

Gambar7 Daftar Pelanggan
Halaman daftar pelanggan berisi tentang daftar pelanggan berdasar kode rbm. Apabila satu nama pelanggan dipilih, maka akan muncul halaman catat meter.

\section{G. Catat Meter}

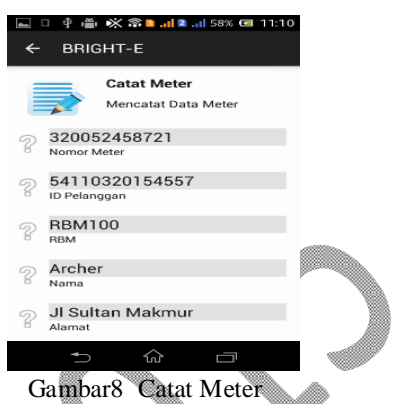

Halaman catat meter berisi tentang form yang akan digunakan oleh Petugas PLN untuk mencatat data meter, mengambil titik latitude dan longitude lokasi neter dan mengambil foto meter. Setelah dilakukan pencatatan data meter, nama pelanggan yang telah dieatat akan masuk ke database dan hilang dari daftar pelanggan.pelanggan dimasukan, maka akan muncul halaman catat meter untuk melakukan pencatatan data meter.

\section{H. Search}

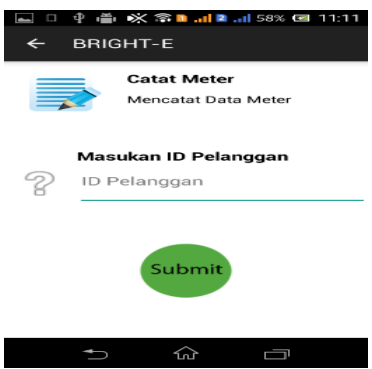

Gambar9 Search

Halaman Search berfungsi untuk melakukan pencatatan meter berdasarkan id pelanggan. Setelah Halaman ambil foto berfungsi untuk mengambil foto meter pelanggan.

ID Pelanggan harus dimasukkan untuk memberi nama foto. Lalu, foto diunggah ke server. 


\section{Hasil Catat Meter}

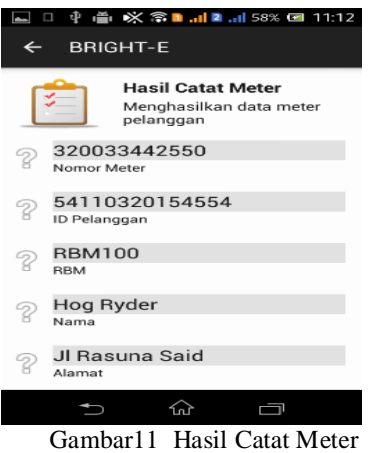

Halaman Hasil Catat Meter berfungsi untuk menampilkan hasil pencatatan data meter di bulan ini.

\section{KESIMPULAN DAN SARAN}

\section{Kesimpulan}

Aplikasi listrik pintar dapat memudahkan Petugas PLN dalam melaksanakan tugasnya seperti mencatat data meter, mengambil titik latitude dan longitude lokasi meter, mengambil foto meter dan melihat hasil pencatatan.

Pada bagian pencatatan data meter, data meter langsung terkirim ke server. Hal ini memudahkan Petugas PLN dalam mendistribusikan data meter ke pusat. Pada bagian pengambilan titik lokasi, titik lokasi dapat terdeteksi dengan sempurna. Hal inf membantu PLN dalam mengetahui apakah Petugas PLN benar - benar melakukan pencatatan data meter. Pada bagian pengambilan foto meter, sistem ini dapat mengambil foto meter dan mengunggahnya ke server. Hal ini membantu Petugas PLN dalam mempercepat pemeriksaan meteran pelanggan tanpa mencatat data meter.

\section{Saran}

Aplikasi ini berjalan secara online sehingga sangat bergantung pada koneksi internet. Apabila koneksi internet buruk, maka proses pencatatan data meter tidak dapat dilakukan. Sebaiknya Petugas PLN menggunakan layanan internet yang sempurna sehingga pencatatan data meter dapat dilakukan dengan baik.

DAFTAR PUSTAKA

[1]

Achmad, S. 2009. Pemrograman Web dengan PHP dan MySQL. Jakărta:Universitas Budi Luhur

[2] ECMA-404. 1999. Introducing JSON http://www.json.org. [26 Maret 2015]

Kadir, A. 2003. Dasar Pemrograman Java 2. Yogyakarta: ANDI

Nugroho, B. 2004. Database Relasional dengan MySQL. Yogyakarta: ANDI

[5] Safaat, N. 2012. Pemrograman Aplikasi Mobile Smartphone dan Tablet PC berbasis Android. Bandung:INFORMATIKA 